\begin{tabular}{|lcc|}
\hline & Osmanlı Medeniyeti Araştırmaları Dergisi \\
Journal of Ottoman Civilization Studies & Sayı 12, Nisan 2021 \& No 12, April 2021 \\
C-ISSN 2458-9519 & C2020 Telif Hakkı OSMED'e aittir & Article Types: Research Article \\
\hline DOI: 10.21021 /osmed.865451 & Makale Türü: Araştırma Makalesi & OSMED, 2021, (12): $32-41$ \\
\hline Geliş Tarihi \& Received: 20.01 .2021 & Kabul Tarihi \& Accepted: 04.02 .2021 &
\end{tabular}

\title{
Reclamation of Agrarian Space in Parts of Ottoman Rumeli, 15th - 16th centuries (Case study of the kaza of Eskihisar Zağra)
}

\section{Milena Petkova*}

\begin{abstract}
The study focuses on the process of reclamation of agrarian space on the territory of the Thracian valley, the kaza of Eskihisar Zağra. Based on different archival material - Ottoman registrations of 15th and 16th centuries, chronicles and ' accounts it reveals features of the local environment and the adaptation of the colonized Muslim population to the conquered territories. In the analyses of the economic activities and the agrarian profile of the villages we use a different approach which is more secure in times of inflation as it was the last decades of the 16th century. We define the number and quantity of different agrarian productions but not as a quantity in money but to show each agrarian production as a tax portion to the total tax portion of the villages instead of comparing enlisted numbers of the registered taxes. It traces back the process of reclamation of the agrarian space by revealing the agrarian profile of the registered newly established settlements. The main observations refer to the role of the seminomadic groups of the yürüks who were engaged more in agriculture, than in pastoral nomadism.
\end{abstract}

Keywords: agriculture, pastoral nomadism, yürüks

\section{$\ddot{O} z$}

Çalışma, Eskihisar Zağra kazasının yer aldığı Trakya vadisindeki tarım alanlarının değerlendirilmesi sürecine odaklanmaktadır. 15. ve 16. yüzyıl Osmanlı kayıtları gibi farklı arşiv materyalleri, kronikler ve seyahat raporları; yerel çevrenin özelliklerini ve bölgeye yerleştirilmiş Müslüman nüfusun fethedilen bölgelere adaptasyonunu ortaya koyuyor. Köylerin ekonomik faaliyetlerinin ve tarım profilinin analizinde, 16. yüzyılın son on yıllarında olduğu gibi enflasyon zamanlarında daha güvenli olan farklı bir yaklaşım kullanıyoruz. Farklı tarımsal üretimlerin sayısını ve miktarını tanımlıyoruz. Fakat bu; para cinsinden bir miktar olarak veya kayıtlı vergilerin miktarlarının listesinin karşılaştırılması şeklinde yapılmıyor. Her bir tarımsal üretimin köylerin toplam vergi miktarındaki payı gösterilmeye çalışılıyor. Kayıtlardaki yeni kurulan yerleşim yerlerinin tarım profílini ortaya çıkararak, tarım alanının değerlendirilmesi sürecini geriye doğru izlemek mümkün olmaktadır. Ana gözlemler, kırsal göçebelikten ziyade tarımla uğraşan yarı göçebe Yörük gruplarının rolüne işaret etmektedir.

Anahtar Kelimeler: tarım, kırsal göçebelik, Yörükler

*(Dr.); Sofia Universoty "St. Kliment Ohridski", mlnpetkova@gmail.com; ORCID: orcid.org/0000-0001-9278-5316

Kaynak Gösterme: Petkova, M. "Reclamation of Agrarian Space in Parts of Ottoman Rumeli, 15th - 16th centuries (Case study of the kaza of Eskihisar Zağra)". Osmanlı Medeniyeti Araştırmaları Dergisi, 12 (2021): 32-41. 
The struggle between the different beyliks in Anatolia led to the birth of the Ottoman state that later became an empire controlling huge territories on three continents - Asia, Africa and Europe. The success of the $16^{\text {th }}$ "classical age" is related not only to political power, expansion of territories and functioning administrative system, but also meant economic growth and struggle for economic hegemony in the Mediterranean world. ${ }^{1}$ This territorial expansion depended on the economic growth and the establishment of a tax system that functioned on each provincial level. In the European territories - Rumeli - one of the challenges they faced during the $14^{\text {th }}$ century from an economic point of view were the depopulated areas including the parts in Thracian valley.

The present paper is based on different archival materials - Ottoman taputahrir deftters of $15^{\text {th }}$ and $16^{\text {th }}$ centuries, travelers' accounts, chronicles, and focuses on the important topic of reclamation of agrarian space in parts of Ottoman Rumeli - the territory of modern Eastern Upper Thrace, where during the $15^{\text {th }}$ and $16^{\text {th }}$ centuries, the Ottoman kaza of Eskihisar Zağra was situated. It aims to reveal the process of the "adaptation" of the colonized Muslim population, predominantly semi-nomadic groups (yürüks), to the local environment and shown by their economic activites. It traces back the process of reclamation of the agrarian space by revealing the agrarian profile of the registered newly established settlements. The approach we apply is to define the number and quantity of different agrarian productions but not as a quantity in money but to show each agrarian production as a tax portion to the total tax portion of the villages. This approach shows the agrarian profile of the lands, i.e. the biggest portion was for the cereals, then the vegetables, vineyards and etc. This provides an excellent possibility for the researcher not only to examine and trace the process of reclamation of agrarian land but to outline the stages of how the environment influenced both - the establishment of a settlement network and modified the agrarian profile of the newly founded villages in some parts of Ottoman Rumeli, present Eastern Upper Thrace.

The kaza of Eskihisar Zağra (Zağra-i Atik), is situated in modern Eastern Upper Thrace and almost overlaps with the present territory of Stara Zagora district. The earliest preserved Ottoman registration of $1489^{2}$ reveals that it was a city with only Muslim population. Since its existence in the Late Medieval Ages is beyond any doubt, the researchers are more likely to define it as a city that has existed before the Ottoman conquest and soon after that, it was repopulated by colonized Muslim population. ${ }^{3}$ The average altitude in this part of the Thracian valley is $160 \mathrm{~m}$, the field is heavily cut by Maritsa (Meriç), Tundzha (Tunca) and Sazliyka rivers' tributaries and this in Ottoman times meant areas with marshy lands.

The old Bulgarian historiography is more likely to see the destruction of settlement network predominantly due to the Ottoman invasions, ${ }^{4}$ while researchers of the last more than 20 years reveal a more complicated process that affected the situation with the settlement network in the valley. It suffered

\footnotetext{
${ }^{1}$ Halil Inalcık, The Ottoman Empire: The Classical Age, 1300 - 1600 (New York: Praeger Publishers, 1973).

2 BOA, TT 26, ff. $2-63$.

${ }^{3}$ Machiel Kiel, "Urban development in Bulgaria in the Turkish Period: The Place of Architecture in the Process," International Journal of Middle East Studies 4/ 2 (1989): 83. See also: Ömer Barkan, "Osmanlı İmparatorluğunda bir iskân ve kolonizasyon metodu olurak. Vakıflar ve temlikler," Vakıflar Dergisi 2 (1934): 283-296; Yusuf Halaçoğlu, "XVI Asırda Çirmen Sancağı'nın Sosyal ve Demografik Tarihi," Türk Tarih Kurumu IV (1956): 1795-1801; Николай Тодоров, „По някои въпроси на балканския град през XV - XVII век, " [Po nyakoi vaprosi na balkanskiya grad prez XV-XVII vek], Исторически Преглед 1 (1962): 32-38; Страшимир Димитров, „За приемствеността в развитието на балканските градове през XV-XVI в., " [Za priemstvenostta v razvitieto na balkanskite gradove prez XV-XVI v.] Балканистика 2 (1987): 9-38.

${ }^{4}$ Васил Златарски, България през XIV-XV век. Лекционен курс [Balgaria prez XIV-XV vek. Lektsionen kurs] (София: Издателство „Изток-Запад“, 2005), 212-242; Петър Ников, „Турското завладяване на България и съдбата на последните Шишмановци, " [Turskoto zavladyavane na Balgaria i sadbata na poslednite Shishmanovtsi] Известия на историческото дружество IX/ 4 (1928): 7-8, 42-46; Димитър Ангелов, „Турското завоевание и борбата на балканските народи против нашествениците," [Turskoto zavoevanie i borbatana balkanskite narodi protiv nashestvenitsite] Исторически преглед 4 (1953): 374-398.
} 
during the long-term war conflicts between the medieval Bulgarian kingdom and the Byzantine Empire which also resulted as depopulation of the area. ${ }^{5}$

Numerous Ottoman sources of $15^{\text {th }}$ and $16^{\text {th }}$ centuries (detailed and synoptic registrations) reveal the dynamics of establishment of settlement network. ${ }^{6}$ The Ottoman chronicles date back the conquest of the region under study soon after the fall of Edirne. ${ }^{7}$ The city and the center of the kaza Eskihisar Zağra by the year of 1489 had a Muslim primary school (muallimhane), mosque, and representatives of the Ottoman administrative and military system, and was part of Paşa sancak - this all by no doubts indicates the early conquest of the territory. ${ }^{8}$ The settlements of the territory of the kaza under study are part of two different military and administrative territorial units - sancaks, in the Ottoman Empire - the Pasha (central parts) and the Niğbolu sancak.

The data preserved in the Ottoman registrations of $15^{\text {th }}$ and $16^{\text {th }}$ centuries provides interesting information on the settlement network, and more precisely, the establishment of a new settlement network, predominantly small and unstable villages with registered yürük taxpayers. In details, the information from the second half of the $15^{\text {th }}$ century (1489-1491) refers to $91 \%$ registered Muslim taxpayers and 9\% Non-Muslims. The formation of the Muslim community is result of migration and colonization of representatives of different parts of Anatolia. As long as the registrations provide information on the region we could assume that the majority of them were from the region of Karaman, Saruhan, Aydin and Menteşe. ${ }^{9}$ Another interesting information is that more than $80 \%$ of them are registered as yürük taxpayers. The characteristics of the settlement network refer to $72.1 \%$ unstable, small newly found villages with Muslim taxpayers and $27.9 \%$ stable, presumable old villages that existed before the Ottoman conquest of the territory of the kaza of Eskihisar Zağra. The new settlements are situated predominantly up to $200 \mathrm{~m}$ altitude with, in the lower parts of Thrace, while the settlements with registered Non-Muslim population are stable and situated above the altitude of $200 \mathrm{~m}$.

Interesting observations could be made referring the villages part of the Niğbolu sancak. Throughout $15^{\text {th }}$ and $16^{\text {th }}$ centuries the ottoman registrations mention five villages, situated on the territory of the kaza of Eskihisar Zağra as part of Niğbolu sancak. ${ }^{10}$ The villages are outside the lower parts of Thrace. They are big and stable settlements which most probably had existed before the ottoman conquest of the area and $86.6 \%$ of the taxpayers are Non-Muslims. We can assume that these settlements represent the

\footnotetext{
${ }^{5}$ Grigor Boykov vd., Balkan City or Ottoman City? A Study on the Models of Urban Development in Ottoman Upper Thrace $15^{\text {th }}-$ $17^{\text {th }} \mathrm{C}$. : Proceedings of the Third International Congress on the Islamic Civilization in the Balkans $1-5$ November 2006, Bucharest, Romania (İstanbul: IRCICA, 2010), 69 - 84; Stefan Dimitrov vd., Demographic characteristic of the urban population in Dimetoka during the XV-XVIth centuries: Dünden Bugüne Batı Trakya (Western Thrace from Past to Today) (Istanbul: Şen Yıldız Yayıncılık Hediyelik Eşya ve Tekstil San ve Tic. Ltd. Şti, 2016), 335-343.

${ }^{6}$ Başbakanlı Osmanlı Arşivi (BOA), İstanbul, TT 26, ff. 1-62; National library "St.St. Cyril and Methodius" (NBKM), Oriental department (Or D), Нк 12/9, f. 39; NBKM, Or D, Сл 7/2, f. 8; NBKM, Or D, F. 88, a.u. 752, f.9; NBKM, Or D, Defters № 649, f. 68, 83-83; BOA TT 77, ff. 459-542; BOA TT 439, ff. 322-328; NBKM, Or D, TH. 37/50; BOA TT 382. ff. 655-666; BOA TT 311, ff. 72-75; BOA TT 494, ff. 421-514; BOA TT 498, ff. 30-39, f. 260, ff. 355-362, ff. 625-639.

7 There are variety of hypotheses referring the year of the conquest of Edirne by the Ottomans. See: Halil Inalcık, The Ottoman Empire, the Classical Age 1300-1600 (New York: Praeger Publishers, 1973), 23-54; Irène Beldiceanu-Steinherr,. "La conquête d'Adrianople par les Turcs: la pénétration turque en Thrace et la valeur des chroniques ottomans," Travaux et Mémoires. Centre d'histoire et de civilisation byzantines 1 (1965): 439-461; Colin Imber, The Ottoman Empire 1300-1481 (Istanbul: Isis Press, 1990), 30; Elizabeth Zacariadu, "The Conquest of Adrianople by the Turks," Studi Veneziani 12 (1970): 211-217.

${ }^{8}$ Rossitsa Gradeva vd., Administrative system and provincial government in the Central Balkan territories of the Ottoman empire, 15th century: The Turks, Cilt 3, Ottomans (Ankara,Yeni Turkiye Publications, 2002), 498-507.

${ }_{9}^{9}$ Ayşe Kayapınar, Levent Kayapınar, vd., Anadolu Beylikleri ve Balkanlar : Anadolu Beylikleri (İstanbul, Siyen Yayınları, 2018), 451

$-524$.

10 NBKM, Or D, Нк 12/9, f. 39; NBKM, Or D, Сл 7/2, f. 8; NBKM, Or D, F. 88, а.u. 752, f.9; BOA 439, ff. 322-328; NBKM, Or D, Tн. 37/50; BOA TT 382. ff. 655-666;
} 
characteristic of the old settlement network. It is suggested that the Ottomans administrated a certain region soon after its conquest. ${ }^{11}$ Furthermore, the mentioned settlements might outline the south border zone of the Second Bulgarian kingdom at the time the ottomans conquered the region since the territory of Niğbolu sancak is considered to match the territory of the Second Bulgarian kingdom. ${ }^{12}$

The registrations for the $16^{\text {th }}$ century confirm what is stated about the second half of the $15^{\text {th }}$ century. The information of the first half of the $16^{\text {th }}$ century refers to the same small and unstable villages in the Thracian valley with predominant Muslim population. ${ }^{13}$ The process of the establishment of a stable settlement network in the region continued for more than a century with ongoing migration of Muslim population a great part of whom were the semi-nomadic groups of the yürüks colonized in the valley and known with their pastoral life and practicing agriculture as a supplement to their economy. The newcomers could easily adapt to the local environment providing huge pasturelands, rivers and swamps - similar to the environment conditions in parts of Ottoman Anatolia where Ottoman registrations show high numbers of registered semi-nomadic groups. ${ }^{14}$ In the second half of the $16^{\text {th }}$ century the different Ottoman registrations show the increase of stable and big settlements (50.9\%) still with predominant Muslim taxpayers of the kaza of Eskihisar Zağra. I assume that these changes in the settlement network refer to the process of sedentarization of some seminomadic groups of the yürüks. A detailed analyses of the agrarian profile of the region will shed more light on the suggested hypothesis.

The reconstruction of the agrarian profile of the region under study will allow us to make observations on the process of adoption of the migrated Muslim population to the local environment. It was stated that the majority of the migrants were representative of the yürüks from different parts of Ottoman Anatolia - Karaman, Aydın, Menteşe, Saruhan. To reveal the process of reclamation of the agrarian space we shall try to define the number and quantity of different agrarian productions as a tax portion to the total tax portion of the villages and not as a quantity in money. This approach shows the agrarian profile of the lands, i.e. the biggest portion was for the cereals, then the vegetables, vineyards and etc. ${ }^{15}$ This approach allow us to make observations regardless inflation processes of the second half of the $16^{\text {th }}$ century ${ }^{16}$ and makes possible to compare different portions estimated for the first and the second

\footnotetext{
${ }^{11}$ Rossitca Gradeva vd., Administrative system and provincial government in the Central Balkan territories of the Ottoman empire, 15th century: The Turks. Vol. 3, Ottomans (Ankara: Yeni Turkiye Publications, 2002), 498-507.

12 Милена Петкова-Енчева vd., Администриране на селища в Тракия през XVI век. Една хипотеза за южната граница на Шишманова България според информацията от османски данъчни регистри om XVI век [Administrirane na selishta $v$ Trakiya prez XVI vek. Edna hopiteza za yuzhnata granitsa na Shishmanova Balgaria spored informatsiyata ot osmanski danachni registry ot XVI vek] : Из практиката на османската канцелария. Сборник материали от международната конференция „Османските регистри - извор за историята на Балканите (София: Народна билбиотека „Св. св. Кирил и Методий, 2011), 195-197.

${ }_{13}$ Milena Petkova, "The Process of Sedentarization of Semi-nomadic Groups of the Yörüks in Parts of $16^{\text {th }}$ Century Ottoman Rumeli: Tax Control or Migration Control?," Journal of Balkan and Black Sea Studies 2//3 (2019): 30 - 33.

14 IIhan Şahin, Osmanlı Döneminde Konar - Göçerler. Incelemeler - Araştırmalar (İstanbul: Eren, 2006), 53-201; Halil Inalcık, The Yürüks: Their Origins, Expansion and Economic Role: The Middle East and the Balkans under the Ottoman Empire. Essays on Economy and Society (Bloomington: Indianda Univerrsity Turkish Studies and Turkish Ministry of Culture Joint Studies, 1993), 97136; Doğan Yörük, “XV - XVI. Asırlarda Akşehir Ken Merkezinin Nüfus Yapısı,” Bilig. Türk Dünyası Sosyal Bilimler Dergisi 45 (2018): 165-198; Rudi Paul Lindner, Nomads and Ottomans in Medieval Anatolia (Bloomington: Indiana University, 1983 ), 35 - 107.

15 The same approach was applied by Stefka Parveva in her research on the region of Edirne and South-west Peloponnese in the $18^{\text {th }}$ century. See: Stefka Parveva, "Rural Agrarian and Social Structure in the Edirne region during the second half of the Seventeenth century," Etudes balkaniques, 3 (2000): 55-90; Idem, Agrarian land and harvest in South-west Peloponnese in the early Eighteenth century: Village, Town and People in the Ottoman Balkans $16^{\text {th }}-$ mid $-19^{\text {th }}$ century (Istanbul: The Isis Press, 2009), 61-110.

16 Ömer L. Barkan, "The Price Revolution of the Sixteenth Century: a Turning Point in the Economic History of the Near East," International Journal of Middle East Studies 6 (1975): 9-28; Linda Darling, Revenue-raising and Legitimacy: Tax Collection and Finance Administration in the Ottoman Empire 1560 - 1660 (Leiden: E.J. Brill), 35-39; Şevket Pamuk, A Monetary History of the Ottoman Empire (Cambridge: Cambridge University Press, 2000), 112-148.
} 
half of the century. The conclusions and observations refer only to registered taxpayers in the defters under study. It is important to outline that the data represents the average production of each of the registered agricultural crops and at least one or two years passed before the Ottomans start to collect what was once declared during the registration. ${ }^{17}$

The village and its boundaries was the most known place for the medieval peasants, the place where they could practice different agricultural activities. Preserved copies of judicial record in the Ottoman registrations provide detailed information on the local environment of the kaza of Eskihisar Zağra. ${ }^{18}$ The data of Ottoman sources reveals regions in Thracian valley with high density of small rivers, swamps and fields of reed and pasturelands on the territory of the kaza. This was the environment where semi-nomadic groups settled and use the land for reclamation and grow of different grains and other crops. In Ottoman Anatolia they reclaimed land in marshy zones to grow wheat, cotton and rice. ${ }^{19}$ The information about swamps in the Thracian valley is provided also in other sources. The History by Leonis Diakoni and his "Historiae", $10^{\text {th }}$ century describe the territory as full of forests and bush woods along "with swamps and small rivers". ${ }^{20}$ An imperial order (ferman) of 1566 related to the forthcoming Ottoman army from Istanbul to Thrace states to build new bridges to secure the moving of the troops. Kethüda Mehmed was in charge to investigate where the swamps and flooded areas were. ${ }^{21}$ The travellers' accounts of $17^{\text {th }}$ and $19^{\text {th }}$ centuries also describe big areas of swamps and bush woods. ${ }^{22}$

We shall start the analyses of the agrarian production with the grains - wheat, barley, rye, millet. The traditional cultivation of cereals on the Balkans served as the main source for food and was an essential product of market exchange. Furthermore, the results of the archaeological excavations refer to the cultivation of different kinds of grains during the period of 11 th -12 th centuries. ${ }^{23}$ Production of grains formed the biggest part of the tax revenues in the region. Wheat is grown in every village on the territory of the kaza of Eskihisar Zağra and often its production was more than the substantial minimum vital. As it is stated for Islamic societies, one-third of the earnings was for the sustenance of the family. ${ }^{24}$ In the region under study the peasants had surpluses of agrarian production. We could assume that these

17 Nicoarâ Beldiceanu, Irène Beldiceanu-Steinherr, "Règlement ottoman concernant le recensement (première moitiè du XVle siècle)," Südost-Forschungen 4 (1978): 1-40; Huri İslamoĝlu-İnan, State and Peasant in the Ottoman Empire: Agrarian Power Relations and Regional Economic Development in Ottoman Anatolia during the $16^{\text {th }}$ Century, Ottoman Empire and Its Heritage Series, Vol 1 (Leiden: E. J. Brill, 1994), 36-37; Suraiya Faroqhi, "Taxation and Urban Activities in Sixteenth Century Anatolia," International Journal of Turkish Studies 1 (1979-1980): 19-53; Spyros Asdrachas, "Aux Balkans du XVe siècle producteurs directs et marches," Etides Balkaniques 3 (1970): 46; John C. Alexander, Counting the Grains: Conceptual and Methodological Issues in Reading the Ottoman Mufassal Tahrir Defters: Mélanges Prof. Machiel Kiel (Arab Historical Review for Ottoman Studies), 19-20] (Zaghouan, 1999): 57-58.

18 BOA, TT 498, f. 361

19 Halil Inalcık, Empire and Population : An Economic and Social History of the Ottoman Empire. Vol. 1 (Cambridge: Cambridge University Press, 1994), 37.

20 In the present paper we use the Bulgarian translation of Leonis Diakoni's "Caloensis Historiae libri decem ve vellitione bellica Nicephori Augusti" published in: Красимира Гагова, Тракия през Българското средновековие. Историческа география [Trakiya prez Balgarskoto srednovekovie. Istoricheska geografiya] (София: Университетско издателство „Св. Климент Охридски, 2002), 22.

${ }^{21}$ Translation of the document is published in: Елена Грозданова, Стефан Андреев, Българите през XVI век по документи om наши и чужди архиви [Balgarite prez XVI vek po dokumenti ot nashi i chuzhdi arhivi] (София: Отечествен фронт, 1986$), 47$. ${ }^{22}$ Немски пътеписи за Балканите XVII - средата на XVIII век.[Nemski patepisi za Balkanite XVII - sredata na XVIII vek] (Coфия: Наука и култура, 1986), 146; Френски пътеписи за Балканите XV - средата на XVIII век.[Frenski patepisi za Balkanite XV sredata na XVIII vek] (София: Наука и култура, 1975), 410-411; Английски пътеписи за Балканите (края на XVI - 30те години на XIX век [Angliyski patepisi za Balkanite (kraya na XVI - 30te godini na XIX vek)] (София: Наука и изкуство, 1987), 555-556.

${ }^{23}$ Борис Борисов, „Икономиката на Североизточна Тракия през XI - XII век, " [Ikonomikata na Severoiztochna Trakiya prez XI - XII vek] Известия на Старозагорския исторически музей 1 (2002): 30-36.

${ }^{24}$ Halil Inalcık, The State Treasury and Budgets : An Economic and Social History of the Ottoman Empire. Vol. 1 (Cambridge: Cambridge University Press, 1994), $77-78$. 
surpluses of grain production were sold at the closest city market by the peasants. The cultivation of different kind of grains provided the livelihood of the population, and it was also part of the necessary amount of food for the domestic animals. ${ }^{25}$ So, the average share of the produced wheat during the $16^{\text {th }}$ century is $54 \%$ and the average amount of the cultivated barley, rye and millet comprises $22.7 \%$. The data refers to all the settlements from the lower parts, i.e. the newly founded villages, and also to settlements above $200 \mathrm{~m}$ altitude. Thus the produced grain production in total on the territory of the kaza of Eskihisar Zağra comprises $76.7 \%$ of all the tax amount.

Agriculture was the most important economic activity in the Ottoman Empire, therefor it is stated to be a priority for the state. The wealth was derived mainly from tax resources in the conquered lands where the main purpose were the collected revenues, i.e. for fiscal reasons. ${ }^{26}$

The next sector of the agrarian economy which is presented in every village on the territory of the kaza of Eskihisar Zağra is the tithe on beehives. The production of honey and wax is in the third place after the production of wheat and other cereals. This production is presented in Muslim and Non-Muslim settlements, which makes it a well-known and well-controlled sector of the agrarian economy widely spread at different altitude. The average share of the tithe on beehives is $3 \%$.

The orchards presented a separate and important part of the income of the settlements with predominant yürük population. There are details on the type of orchards in some of the registered villages - pears and others, but the information is insufficient to make observations on the species of orchards in the Thracian valley. Very often the taxation of orchards is entered together with the walnut trees. During the $19^{\text {th }}$ century the production of walnut trees were used to produce oil with better quality than the olive oil. ${ }^{27}$ During the $16^{\text {th }}$ century the average amount of the portion of the orchards is $1 \%$ of all the tax revenues.

The vegetable gardens were also located within the village boundaries, as it is described in the documents providing information on the village borders (sinirname) they were situated near wells, channels or small river inflows. The portions of the vegetable gardens is only $0.5 \%$ of the total registered agrarian production.

The share of lentil comprised only $0.1 \%$ of the total amount of the tax revenues during the $16^{\text {th }}$ century. It is noteworthy that the production of legumes are too poorly represented in the tax registrations. For the second half of the century when the registrations seem to be more complete the data of absence of cultivated legumes is even more surprising. I assume that the drought during the second half of the $16^{\text {th }}$ century that affected the production of the other agricultural products like the grains for example, affected the cultivation of the legumes as well.

In addition to growing grains, vegetable and orchards, the peasants in the Thracian valley and the region of the kaza of Eskihisar Zağra cultivated vineyards whose average portion for the $16^{\text {th }}$ centuries is $0.4 \%$. It is interesting to observe that in some of the settlements for which no vineyards are recorded

\footnotetext{
25 Цветана Георгиева, „Хлябът, който разделя и събира светове“ [Hlyabat, koito razdelya svetove] Български фолклор 1 (1993): 7-19; Страшимир Димитров vd., Добруджанското земеделие през XVI век [Dobrudzhanskoto zemedelie prezz ZVI vek] : Сборник в чест на проф. Хр. Гандев. Изследвания по случай 75 години от рождението му (София: БАН, 1985), 112113; Gilles Veinstein vd., La grande sécheresse de 1560 au Nord de la Mere Noire: perceptions et réactions des autoritiés ottomanes: Natural Disasters in the Ottoman Empire. Halcyon Days in Crete III (Crete: Crete University Press, 1999), 273-278; Evangelia, Balta, L'Eubée a la fin du XVe siècle. Économie et Population. Les registres de l'année 1474 (Athens: , 1989), 64-71; Huri, İslamoğlu-İnan, State and Peasant in the Ottoman Empire: Agrarian Power Relations $n$ Regional Economic Development in Ottoman Anatolia during the 16th c. (Leiden: Brill, 1994), 45-46.

26 Halil Inalcık, The Rural Landscape and the Settlement of Nomads : An Economic and Social History of the Ottoman Empire, 1300 - 1914 (Cambridge: Cambridge University Press, 1994), 158-161.

27 Eтнография на България [Etnografiya na Bulgaria] (София: БАН, 1964), 24 - 25.
} 
register provides information on tax collected for the production of wine or the import of wine (fuç-i hamır). This information refers only to a small number of settlements -6 , with predominant Non-Muslim population.

The average amount of the production of rice during the $16^{\text {th }}$ century is $4 \%$ and only Muslim population is engaged in its cultivation. The rice was cultivated near the river inflows of the Thracian valley with predominant yürük settlements. I assume this was not only related to their ability to reclaim land from marshy areas but from a certain point of view reveals processes of the sedentarization of the semi-nomadic groups. The issue of whether it was a policy of the ottoman state to settle nomadic groups is still an open discussion, though most of the researchers accept the thesis that it was a state policy part of the conquest of depopulated areas. ${ }^{28}$

The observations on the livestock breeding are limited due to the characteristic of the sources which are related to present data of tax revenues used for the formation of different revenues like timars and zeamet. Since the yürüks were the predominant Muslim population in the village of the kaza of Eskihisar Zağra, the sheep breeding could have comprised large income for the state treasury and therefor registered as mikatta's which are not included in the taputahrir defter under study. Therefore, the full portion of the livestock breeding could not be estimated using only taputahrir registrations for the study. What the registrations under study show is an average portion referring the registered livestock breeding during the $16^{\text {th }}$ century comprising only $7.8 \%$.

\section{Conclusion}

Despite the limitation framework of the research due to the specifics of the historical sources, the results allows to assume the following suggestions. The biggest portion of the agricultural production was the one of the grains where the wheat dominated on the territory of the kaza of Eskihisar Zağra. The registered taxpayers cultivated orchards, had vegetable gardens, vineyards - the last ones are well represented in the village with Non-Muslim taxpayers, in the area between $200-600 \mathrm{~m}$ altitudes. The rice is presented only in the Muslim villages, in the lower parts of Thrace. We could assume that a certain percent of the taxpayers were engaged in sheep breeding, the incomes from it were not included in the registers under study. Muslims are the majority of the registered taxpayers and representatives of the seminomadic groups. They established new settlement network in the Thracian valley and managed to reclaim land of marshy and bushy areas near the river inflows. The process of adoption to the conquered lands continued more than a century since the Ottoman conquest in the second half of the $14^{\text {th }}$ century. This process reveals the sedentarization of parts of the semi-nomadic groups which are presented as reaya engaged in different agricultural production - grains, vegetables, orchards, legumes, etc. This sedentarization and agricultural activities led to the "economic" conquest of the territory of the kaza of Eskihisar Zağra.

\footnotetext{
28 Ömer L. Barkan, "Osmanli Imparatorlugunda Bir Iskân ve Kolonizasyon Metodu Olarak Sürgünler [Part 1]," Istanbul Üniversitesi Iktisat Fakültesi Mecmuasi 11 (1949-50): 524-569; Ömer L. Barkan, "Osmanli Imparatorlugu'nda Bir Iskân ve Kolonizasyon Metodu Olarak Sürgünler [Part2]," Istanbul Üniversitesi Iktisat Fakültesi Mecmuasi 13 (1952): 60 - 81; Ömer L. Barkan, "Osmanli Imparatorlugunda Bir Iskân ve Kolonizasyon Metodu Olarak Sürgünler [Part 3]," Istanbul Üniversitesi Iktisat Fakültesi Mecmuasi 14 (1953-54): 20 - 236; Halil Inalcik, "Ottoman Methods of Conquest," Studia Islamica 2 (1954): 103 - 129; Harun Yeni, "The Utilization of Mobile Groups in the Ottoman Balkans: A Revision of General Perception". Oriental Archive, 83 (2013): $83-205$.
} 


\section{Bibliography}

Alexander, John C. Counting the Grains: Conceptual and Methodological Issues in Reading the Ottoman Mufassal Tahrir Defters : Mélanges Prof. Machiel Kiel (Arab Historical Review for Ottoman Studies), 19-20] Zaghouan, 1999.

Asdrachas, Spyros. "Aux Balkans du XVe siècle producteurs directs et marches.” Etides Balkaniques 3 (1970): $20-56$.

Balta, Evangelia. L'Eubée a la fin du XVe siècle. Économie et Population. Les registres de l'année 1474. Athènes: Association des Études d'Eubée, 1989.

Barkan, Ömer. "Osmanli Imparatorlugunda Bir Iskân ve Kolonizasyon Metodu Olarak Sürgünler [Part 1.” Istanbul Üniversitesi Iktisat Fakültesi Mecmuasi 11 (1949-50): 524-69.

Barkan, Ömer. "Osmanli Imparatorlugu'nda Bir Iskân ve Kolonizasyon Metodu Olarak Sürgünler [Part2].” Istanbul Üniversitesi Iktisat Fakültesi Mecmuasi 13 (1952): 60 - 81.

Barkan, Ömer. "Osmanli Imparatorlugunda Bir Iskân ve Kolonizasyon Metodu Olarak Sürgünler [Part 3].” Istanbul Üniversitesi Iktisat Fakültesi Mecmuasi 14 (1953-54): 20 - 236.

Barkan, Ömer. "The Price Revolution of the Sixteenth Century: a Turning Point in the Economic History of the Near East." International Journal of Middle East Studies 6 (1975): 9-28.

Beldiceanu, Nicoarâ., Irène Beldiceanu-Steinherr. "Règlement ottoman concernant le recensement (première moitiè du XVIe siècle)." Südost-Forschungen 4 (1978): 1-40.

Beldiceanu-Steinherr, Irène. La conquête d'Adrianople par les Turcs: la pénétration turque en Thrace et la valeur des chroniques ottomans : Travaux et Mémoires. Centre d'histoire et de civilisation byzantines, V. 1. Paris: Edition E. de Boccard, 1965, 439-461.

Boykov, Grigor vd. Balkan City or Ottoman City? A Study on the Models of Urban Development in Ottoman Upper Thrace $15^{\text {th }}-17^{\text {th }} \mathrm{c}$. : Proceedings of the Third International Congress on the Islamic Civilization in the Balkans 1 - 5 November 2006, Bucharest, Romania. İstanbul: İRCICA, 2010.

Barkan, Ömer. "Osmanlı İmparatorluğunda bir iskân ve kolonizasyon metodu olurak. Vakıflar ve temlikler."Vakıflar Dergisi 2 (1934): 283 - 296.

Darling, Linda. Revenue-raising and Legitimacy: Tax Collection and Finance Administration in the Ottoman Empire 1560 - 1660. Leiden: E.J. Brill., 1996.

Dimitrov, Stefan vd. Demographic characteristic of the urban population in Dimetoka during the XVXVIth centuries: Dünden Bugüne Batı Trakya (Western Thrace from Past to Today). Istanbul: Şen Yıldız Yayıncılık Hediyelik Eşya ve Tekstil San ve Tic. Ltd. Şti, 2016.

Faroqhi, Suraiya. "Taxation and Urban Activities in Sixteenth Century Anatolia." International Journal of Turkish Studies 1 (1979-1980): 19-53.

Gradeva, Rossitsa. "Administrative system and provincial government in the Central Balkan territories of the Ottoman empire, 15th century." The Turks, Ottomans 3 (2002): 498-507.

Halaçoğlu, Yusuf. “XVI Asırda Çirmen Sancağı'nın Sosyal ve Demografik Tarihi.” Türk Tarih Kurumu IV (1956): 1795-1801.

Inalcik. Halil. "Ottoman Methods of Conquest.” Studia Islamica 2 (1954): 103 - 129.

Imber, Colin. The Ottoman Empire 1300-1481. Istanbul: The Isis Press, 1990.

İnalc1k, Halil. The Ottoman Empire, the Classical Age, 1300-1600. New York: Praeger Publishers, 1973. 
İnalc1k, Halil. The Rural Landscape and the Settlement of Nomads: An Economic and Social History of the Ottoman Empire, 1300 - 1914. Ed. Inalcik, H. \& Quataert, D. Cambridge: Cambridge University Press, 1994.

İnalc1k, Halil. The Yürüks: Their Origins, Expansion and Economic Role. : The Middle East and the Balkans under the Ottoman Empire. Essays on Economy and Society. Bloomington: Indianda Univerrsity Turkish Studies and Turkish Ministry of Culture Joint Studies, 1993.

İslamoğlu-İnan, Huri. State and Peasant in the Ottoman Empire: Agrarian Power Relations and Regional Economic Development in Ottoman Anatolia during the 16thc. Leiden: Brill, 1994.

Kalionski, Alexei. Yürüks in the Ottoman Balkans. Sofia: Gutenberg Publishing House, 2020.

Kayapınar, Ayşe., Kayapınar, Levent. vd., Anadolu Beylikleri ve Balkanlar : Anadolu Beylikleri (İstanbul, Siyen Yayınları, 2018), $451-524$.

Kiel, Mahiel. "H'razgrad - Hezargrad - Razgrad. The Vicissitudes of a Turkish Town in Bulgaria (Historical, Demographical Economic and Art Historical Notes).”Turcica XXI-XXIII (1991):495563.

Kiel, Machiel. "Urban development in Bulgaria in the Turkish Period: The Place of Architecture in the Process." International Journal of Middle East Studies 4// 2 (1989): 83-97.

Lindner, Rudi Paul. Nomads and Ottomans in Medieval Anatolia. Bloomington: Indiana University, 1983.

Pamuk, Şevket. A Monetary History of the Ottoman Empire. Cambridge: Cambridge University Press, 2000.

Parveva, Stefka. "Rural Agrarian and Social Structure in the Edirne region during the second half of the Seventeenth century." Etudes balkaniques 3 (2000): 55-90.

Parveva, Stefka. Agrarian land and harvest in South-west Peloponnese in the early Eighteenth century :Village, Town and People in the Ottoman Balkans $16^{\text {th }}-$ mid $-19^{\text {th }}$ century Istanbul: The Isis Press, 2009, 61-110.

Petkova, Milena. "The Process of Sedentarization of Semi-nomadic Groups of the Yörüks in Parts of $16^{\text {th }}$ Century Ottoman Rumeli: Tax Control or Migration Control?." Journal of Balkan and Black Sea Studies 2//3 (2019): 25 - 43.

Şahin, İlhan. Osmanlı Döneminde Konar - Göçerler. İncelemeler - Araştırmalar. İstanbul: Eren, 2006.

Veinstein, Gilles. La grande sécheresse de 1560 au Nord de la Mere Noire: perceptions et réactions des autoritiés ottomanes : Natural Disasters in the Ottoman Empire. Halcyon Days in Crete III. Crete: Crete University Press, 1999, 273-278.

Yeni, Harun. "The Utilization of Mobile Groups in the Ottoman Balkans: A Revision of General Perception". Oriental Archive, 83 (2013): 83- 205.

Yörük, Doğan. “XV - XVI. Asırlarda Akşehir Ken Merkezinin Nüfus Yapısı.” Bilig. Türk Dünyası Sosyal Bilimler Dergisi 45 (2018): 165-198.

Zacariadu, Elizabeth. "The Conquest of Adrianople by the Turks." Studi Veneziani 12 (1970): 211-217.

Ангелов, Димитьр. „Турското завоевание и борбата на балканските народи против нашествениците.“ [Turskoto zavoevanie i borbatana balkanskite narodi protiv nashestvenitsite] Исторически преглед IX// 4 (1953): 374-398.

Английски пътеписи за Балканите (края на XVI - 30те години на ХIX век [Angliyski patepisi za Balkanite (kraya na XVI - 30te godini na XIX vek)]. София: Наука и изкуство, 1987. 
Борисов, Борис. „Икономиката на Североизточна Тракия през XI - XII век.“ [Ikonomikata na Severoiztochna Trakiya prez XI - XII vek.] Известия на Старозагорския исторически музей 1 (2002): 20-36.

Гагова, Красимира. Тракия през Българското средновековие. Историческа география [Trakiya prez Balgarskoto srednovekovie. Istoricheska geografiya]. София: Университетско издателство „Св. Климент Охридски, 2002.

Георгиева, Цветана. „Хлябът, който разделя и събира светове.“ [Hlyabat, koito razdelya svetove] Български фолклор 1 (1993): 7-19.

Грозданова, Елена, Андреев, Стефан. Българите през XVI век по документи от наши и чужди архиви [Balgarite prez XVI vek po dokumenti ot nashi i chuzhdi arhivi]. София: Отечествен фронт, 1986.

Димитров Страшимир. Добруджанското земеделие през XVI век [Dobrudzhanskoto zemedelie prezz ZVI vek] : Сборник в чест на проф. Хр. Гандев. Изследвания по случай 75 години от рождението му. София: БАН, 1985.

Димитров, Страшимир. „За приемствеността в развитието на балканските градове през XV-XVI в.“ [Za priemstvenostta v razvitieto na balkanskite gradove prez XV-XVI v.] Балканистика 2 (1987): 9-38.

Немски пътеписи за Балканите XVII - средата на XVIII век.[Nemski patepisi za Balkanite XVII sredata na XVIII vek]. София: НАука и култура, 1986.

Петкова-Енчева, Милена. „Администриране на селища в Тракия през XVI век. Една хипотеза за южната граница на Шишманова България според информацията от османски данъчни регистри от XVI век“" [Administrirane na selishta v Trakiya prez XVI vek. Edna hopiteza za yuzhnata granitsa na Shishmanova Balgaria spored informatsiyata ot osmanski danachni registry ot XVI vek], Из практиката на османската канщелария. Сборник материали от международната конференция „, Османските регистри -извор за историята на Балканите“, София: Народна библиотека „Св. св. Кирил и Методий“, 2011, 195-197.

Френски пътеписи за Балканите XV - средата на XVIII век.[Frenski patepisi za Balkanite XV sredata na XVIII vek].София: Наука и култура, 1975.

Златарски, Васил. България през XIV-XV век. Лекционен курс. [Balgaria prez XIV-XV vek. Lektsionen kurs]. София: Издателство „Изток - Запад“, 2005.

Ников, Петър. „Турското завладяване на България и съдбата на последните Шишмановци.“ [Turskoto zavladyavane na Balgaria i sadbata na poslednite Shishmanovtsi.] Известия на историческото дружество 3 (1928).

Тодоров, Николай. „По някои въпроси на балканския град през XV - XVIIвек.“ [Po nyakoi vaprosi na balkanskiya grad prez XV-XVII vek.] Исторически преглед, 1 (1962): 32 - 48. 